\title{
FACTORS AFFECTING VEGF EXPRESSION IN ENDOMETRIOSIS PATIENTS
}

\author{
Rochip Mursidi \\ Department of Obstetrics and Gynecology, \\ Dr. Moewardi Hospital, Surakarta
}

\begin{abstract}
Background: Patients with endometriosis have abnormal endometrial receptivity that causes embryonic implantation failure. Some factors play role in endometrial receptivity, one of which is angiogenesis factor. VEGF is an angiogenesis factor that plays an important role in human body as well as in pathological condition of endometriosis. The purpose of this study was to examine the effect of clinical and epidemiological factors on VEGF expression with endometrial receptivity in endometriosis patients.
\end{abstract}

Subjects and Method: This was a cross sectional study. This study was conducted at Sekar Clinics, Dr. Moewardi Surakarta, and Islamic Hospital, Klaten, Central Java, from January to November 2014. A sample of 60 women undergoing sterilization consisting of 30 patients with infertile endometriosis and 30 patients with no endometriosis who underwent laparoscopy or laparotomy, were selected for this study. The dependent variable was VEGF expression. The independent variables were menstrual disturbance, dysmenorrhea, and illness history. VEGF expression was measured by immunohistochemical (IHC) examination in the secretion phase as endometrial receptive marker. Hysterolaparoscopy was performed in the secretion phase, i.e. the 19th day to the 24th day of the menstrual cycle. Patients with endometriosis underwent biopsy of endometrial tissue during hysterolaparoscopy for IHC examination at Pathology Anatomy Laboratory, Dr. Sardjito Hospital. The data were analyzed by logistic regression.

Results: Menstrual disturbance $(\mathrm{OR}=0.18 ; \mathrm{p}=0.071)$, dysmenorrhea $(\mathrm{OR}=$ $0.22 ; \mathrm{p}=0.024)$, and illness history $(\mathrm{OR}=0.70 ; \mathrm{p}=0.685)$ decreased VEGF expression.

Conclusion: Menstrual disturbance, dysmenorrhea, and illness history, decrease VEGF expression.

Keywords: VEGF, clinical factor, epidemiological factor, endometriosis

Corespondence: Rochip Mursidi. Department of Obstetrics and Gynecology, Dr. Moewardi Hospital, Surakarta.

Email: rochip_10m@ymail.com. Mobile: +6285328222324. 